\begin{tabular}{|l|l|l|l|l|}
\hline Philologus & 130 & 1986 & 2 & $187-190$ \\
\hline
\end{tabular}

Elvira Gaxgetia

\title{
FURTHER COMMENTS ON POXY. 2888
}

Crates, Seleucus and ancient geography and anthropology

1. Under number 2888 of the $39^{\text {th }}$ volume of the papyri of Oxyrhynchus Lobel edited a commentary on the Odyssey, which he introduced (p. 43) with a rather impatient prologue. He said that the papyrus "is of no great interest and I could have wished that a collection of fragments which fitted almost without residue had contained a text of more value". We don't know what the late distinguished E. Lobel expected to find, but on certain very obscure and badly known areas of antiquity, these quite well preserved lines might throw some light.

2. POxy. 2888 and Diogenes of Oenoanda

Lobel suggested that the author of the commentary was a Pergamene rather than an Alexandrian scholar and, certainly, Crates Mallotes is named in col. iii. 6. This accepted, something that also strikes the reader is a certain mild philanthropic spirit in the text where the arguments used recall the Epicurean author Diogenes of Oenoanda.

For instance, the argument that reduces ad absurdum (POxy. 2888. ii. 13) the idea that a certain reading could be erased from all manuscripts by an order has a striking parallel with Diogenes of Oenoanda's "great denominating assembly". Diogenes believed that, in the evolution of mankind, it would be most ridiculous to assemble all men (or things?) to give names and so create language by decree:

POxy. 2888. ii. 13 (p. 47 and 45)

$$
\tau[0 \tilde{\tau} \tau] \circ \delta^{\prime} \varepsilon u ̛ \eta \vartheta q \varepsilon . \gamma \varepsilon \lambda 0 \tilde{-}-
$$

$[0] \nu \gamma \dot{\alpha} \rho \tau[\grave{o} \dot{u} \pi 0] \lambda \alpha \mu \beta[\dot{\alpha} \nu] \varepsilon เ \nu \dot{\varepsilon} x$

$\pi \dot{\alpha} v \tau \omega[\nu.] . . \alpha \dot{\alpha} v i \cdot \gamma p \alpha \dot{\alpha} \phi \omega \nu$

$x \alpha \vartheta \alpha_{\alpha}^{\prime} \pi[\varepsilon \rho \dot{\alpha}] \pi \dot{o} \pi \rho \circ \sigma \tau \dot{\alpha} \gamma \mu \alpha \tau \sigma \varsigma$
Diog. Oen. 10. iv. 3 (Chilton)

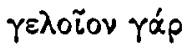

$$
\begin{aligned}
& \text { ह่ } \sigma \tau \iota, \mu \tilde{\alpha} \lambda \lambda \text { ov } \delta \dot{\varepsilon} \pi \alpha \nu-
\end{aligned}
$$

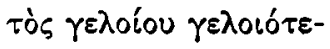

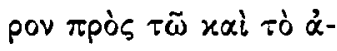

$$
\begin{aligned}
& \delta \dot{v} \nu \alpha[\tau] \circ[\nu] \propto \dot{v} \tau \tilde{\omega} \pi \rho \circ \sigma \varepsilon \tilde{\imath}- \\
& v \alpha \iota, \sigma[u v \alpha] \gamma \alpha \gamma \varepsilon \tilde{\varepsilon} \nu \mu \varepsilon^{\prime} v \\
& \tau i v \alpha \tau \dot{\alpha}[\tau 0] \sigma \alpha \dot{\alpha} \delta \varepsilon \pi \lambda \dot{\gamma} \theta \eta
\end{aligned}
$$

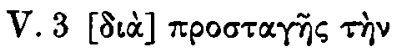

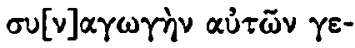

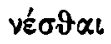


Even when it is possible that our papyrus commentary antedates Diogenes. it is interesting to notice the common philosophical ground and to what extent Diogenes drew the type of his arguments from Homeric scholarship.

As regards anthropology, Diogenes depicted the gradual evolution of mankind from utter barbarism to civilization in fragments 9 and 10 of the great inscription of the citadel of Oenoanda. This concern is not far from the mind of the papyrus commentator when in column i. 22 he explains Eidothea's deceiving of her father

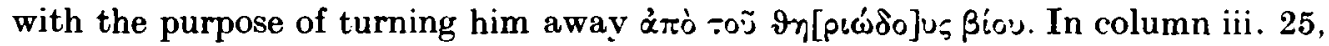

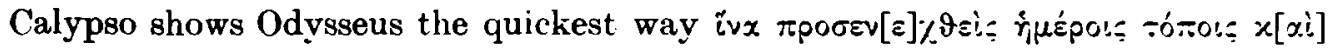

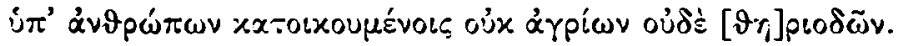

\section{POxy. 2888 on geography and oceanography}

Lobel had already noticed that the papyrus doesn't really seem an elucidation of the text of the Odyssey ; Luppe ${ }^{2}$, in this thorough philological paper finds no evidence of lemmatization. In fact, the author of the commentary deals with the wanderings of two Homeric heroes and with the solving of actual astronomical ${ }^{3}$, nautical and geographical problems in relation to those travels.

As we know from the fragments collected by Mette 4 , Crates Mallotes dealt with Odysseus' and Menelaus' wanderings ${ }^{5}$. In both cases he believed that the travels had taken place, at least partly, in the Atlantic Ocean, though, as far as we knew until the finding of this papyrus, in a very abstract way, as no geographical names appeared. Only in the resumé by Aristonicus in Strabo 1.2.31, is it possible to assume that Crates and his school believed that Menelaus' journey was a periplus

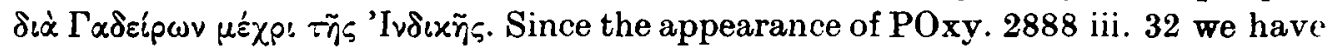
a geographical name (the Pillars of Heracles) and one of the first nautical instructions of how to enter the Mediterranean from the Atlantic Ocean. This was formulated by Homeric scholars trying to solve problems of interpretation by relating Homer to the actual astronomical and geographical knowledge of their time.

After Lobel, Luppe and F. Galiano's ${ }^{6}$ comments and explanations, it is quite clear that what is meant in the papyrus is that with Ogygia in North Western Atlantic Ocean it would be impossible to reach the Mediterranean directly $\dot{\alpha}]$ rò

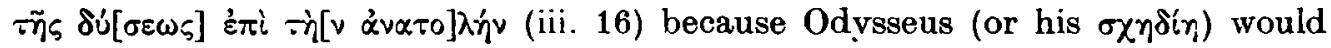

1 Cf. Lobel's parallel to POxy. 2888 Fr. (a) col. i 13, p. 46 from Sch. Od.9.60.

2 W. Luppe, Odysseus' Rückkehr von Kalypso. Ein Beitrag zum Odyssee-Kommentar P.Oxy. 2888, Archiv für Papyrusforschung 24-25, 1976, 39-46. Cf. p. 40. See also M. Fernández-Galiano, Diez años de papirología, Estudios Clásicos 84, 1979, 289-290, and his introduction to the translation of the Odisea by J. M. Pabón, Madrid 1982 (Biblioteca Clásica Gredos 48).

${ }^{3}$ An astronomical resumé may be found also in Diog. Oen. 8 (Chilton).

4 H. J. Mette, Sphairopoiia. Untersuchungen zur Kosmologie des Krates von Pergamon, München 1936.

"Odysseus: Fr. 30-32 (Mette), cf. Sch. Il. 21.195b (Erbse); Menelaus: Fr. 45 (Mette).

- See our n. 2. 
encounter the Iberian peninsula or, as far as they knew, a rather undifferentiated coas:tline running from the Iberian peninsula Northwards.

There is further evidence that some commentator thought that the verse

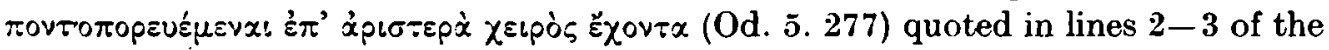
third column of the papyrus was referring to the journey from the Atlantic Ocemn to the East. Such evidence is supported by the Odyssean scholium ${ }^{7}$ (from the Harleianus) to this verse,

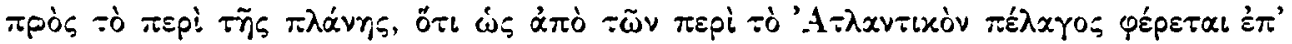

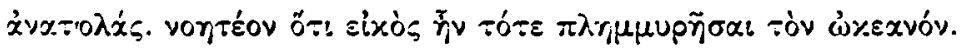

In the rather enigmatic second part of the scholium we may have a clue to why Seleucus (of Babylon) is mentioned in col. iii. 18 of POxy. 2888. It is in a list of theoreticians on the phaenomenon of tides that Seleucus was known as an opponent to Crates Mallotes ${ }^{8}$,

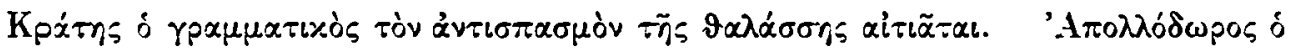

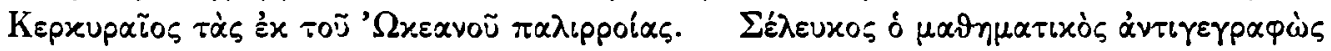

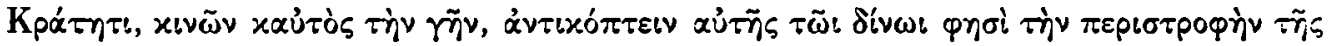

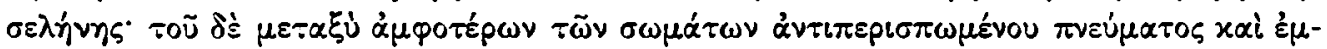

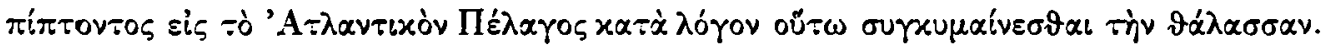

Seleucus contradicted Crates on oceanographic points. Possibly, he thought,

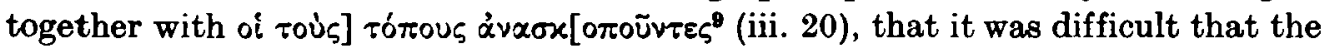
Mediterranean Sea could be reached from the Atlantic Ocean during ebb-tide.

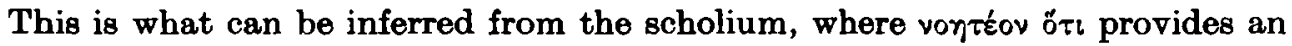
interesting parallel to vooṽ $\sigma$ เv $\delta^{\prime}$ ó $\tau$ : of 1.21 , col. iii of the papyrus. We must also take into account that Seleucus is quoted by Posidonius ${ }^{10}$ as an authority on tides when dealing with the phaenomenon in the proximity of Cadiz.

Another condition to steer safely into the Mediterranean (iii.39) would be

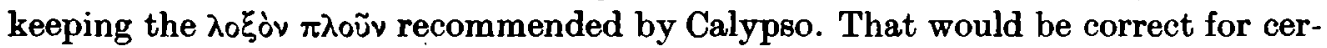
tain geographers in I B.C./ I A.D., as for instance Mela. A vessel sailing parallel to the coast coming from a North-western position ${ }^{11}$ and trying to arrive at cape

7 I suppose line 21 is G. Dindorf, Scholia graeca in Homeri Odysseam, Oxford 1855 (1962) 271 is an obvious misprint for $\tilde{i}_{i}$. It is correctly edited in T. A. Cramer, Anecdota Graeca, Oxford 1841 [(0) 1967] III, 447. In A. Ludwich, Scholia in Homeri Odyssea A 1-309 auctiora et emendatiora, Königsberg 1880-1890 (1966) an apparently phantastic location for Calypso's island may be found. Crates considered also, as far as we know, vague north European locations for some parts of the Odyssey: cf. Fr. 37 (Mette).

${ }^{8}$ Crates Mallotes Fr. 7. Cf. also Fr. 35 (Mette).

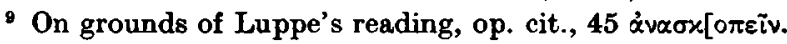

10 A 'moderate Cratetean himself', R. Pfeiffer, History of Classical Scholarship, Oxford 1971, 1, 241 and n. 1. See Posidonius Fr. 218 (Edelstein-Kidd).

11 We don't want to say "at the height of Cape St. Vincent", because its position (see the dis. cussion between Erathostenes and Apollodorus in Str. 2.11) and orientation was quite muddled; even for Mela (3.3 Parroni): huc egressos sequentesque ea quae exeuntibus dextra sunt aequor Atlanticum et ora Baeticae frontis excipit, quae, nisi quod semel iterumque paululum in semet abducitur, 
Trafalgar, would have to take a slant steer, as it may be inferred from he reverse description in Pomponius Mela 2.96 (Parroni 1.984):

tum Melaria et Bel[l]o et Baesippo usque ad Iunonis promunturium oram freti occupat. illud iam in occidentem et oceanum obliquo iugo excurrens, atque ei quod in Africa[m] Ampelusiam esse dixeramus adversum, qua nostra maria sunt finit Europen.

\section{Geography and anthropology}

Calypso advises the r $\alpha$ ' shorter, possibly a land route ${ }^{12}$, is rejected because the author of the papyrus commentary believes in the uncivilised state of the people beyond the Pillars of Hercules. At the time of this commentary, fabulous Erytheia and Tartessus have vanished and what is left is a rather ancient and low level of knowledge of the

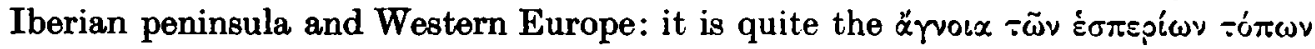
that Strabo complained of (3.4.4).

For the commentator so concerned with rescuing mankind (and even fabulous beings such as Proteus) from a savage state, progress meant a further geographical step, that is, to arrive as soon as possible $\pi p o \dot{s}$ sòv $x \times \vartheta$ ' 'H

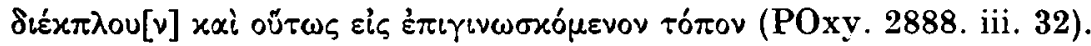

\section{Consejo Superior de Investigaciones Cientificas}

Instituto de Filologia

28014 Madrid/Spain

usque ad fluvium Anam paene recta est ... (3.7) at Lusitania trans Anam, qua mare Atlanticum spectat, primum ingenti impetu in altum abit, dein resistit ac se magis etiam quam Baetica abducit. qua prominet, bis in semet recepto mari, in tria promunturia dispergitur: Anae proximum, quia lata sede procurrens paulatim se ac sua latera fastigat, Cuneus ager dicitur, sequens Sacrum vocant, Magnum quod ulterius est.

For the problems in these lines, see the commentary in the recent edition of Mela by P. Parroni, Rome 1984, 379-380, 382-383. We must have in mind the form of Hispania found in Plinius NH 4.113 where the peninsula offers an almost continuous frons from the strait of Gibraltar to the Cabo de Roca, believed to be the angle where the Atlantic Ocean and the Bay of Biscay (Mar Cantábrico) meet. Cape St. Vicent is seen as a simple protrusion in this frons (Plinius NH 4.115). This presupposes a "triangular" form of the Iberian peninsula, an idea which, in spite of Strabo's more correct views, shall reach early medieval geographers: see L. Molina, Orosio y los geógrafos hispanomusulmanes, Al-Qantara V, 1984, 63-92. If this geographical view formed part of the "chart of Agrippa" (not unknown by Mela, see Parroni, op. cit., 17), it would also explain the belief of an almost northwards orientation of the entrance to the straits of Gibraltar in Avienus: A. Berthelot, Festus Avienus. Ora maritima, Paris 1934, vv. 88 ss. and comm. in p. 7,57. Contra A. Schulten, Avieno. Ora maritima (Fontes Hispaniae Antiquae 1), Barcelona $1955^{2}, 93$ (1 $^{\text {st }}$ ed. 1922).

12 ..."that Kalypso recommends not the shortest route, but the one that soonest brings Odysseus into regions where he would be forwarded", Lobel, comm. to POxy. 2888. iii. 21. A land route from the Atlantic coast to the Mediterranean Sea (from Ophiussa to Mare Sardum) is contemplated in Avienus vv. 148-151: see Schulten, op. cit., comm. in p. 99. 